\title{
Portal Thrombosis in Cirrhosis: Role of Thrombophilic Disorders
}

\author{
José Ignacio Fortea ${ }^{1,2,3, *,+} \mathbb{1}$, Inés García Carrera ${ }^{1,+}{ }^{+}$Ángela Puente ${ }^{1,2,3}$, \\ Antonio Cuadrado 1,2,3@D, Patricia Huelin 1,2,3, Carmen Álvarez Tato ${ }^{1}$, \\ Paloma Álvarez Fernández ${ }^{1}$, María del Rocío Pérez Montes ${ }^{4}$, Javier Nuñez Céspedes ${ }^{4}$, \\ Ana Batlle López ${ }^{4}$, Francisco José González Sanchez ${ }^{5}$, Marcos López Hoyos 2,6 (D), \\ Javier Crespo $1,2,3$ and Emilio Fábrega ${ }^{1,2,3}$ \\ 1 Gastroenterology and Hepatology Department, University Hospital Marqués de Valdecilla, \\ 39008 Santander, Spain; ines.garciac@scsalud.es (I.G.C.); angelam.puente@scsalud.es (Á.P.); \\ antonio.cuadrado@scsalud.es (A.C.); patricia.huelin@scsalud.es (P.H.); carmenalvtato@hotmail.com (C.Á.T.); \\ palomaalvrz@gmail.com (P.Á.F.); javiercrespo1991@gmail.com (J.C.); emilio.fabrega@scsalud.es (E.F.) \\ 2 Group of Clinical and Translational Research in Digestive Diseases, Health Research Institute Marqués de \\ Valdecilla (IDIVAL), 39011 Santander, Spain; marcos.lopez@scsalud.es \\ 3 Biomedical Research Networking Center in Hepatic and Digestive Diseases (CIBERehd), \\ 28029 Madrid, Spain \\ 4 Hematology Department, University Hospital Marqués de Valdecilla, 39008 Santander, Spain; \\ mdelrocio.perez@scsalud.es (M.d.R.P.M.); javier.nunezc@scsalud.es (J.N.C.); mana.batlle@scsalud.es (A.B.L.) \\ 5 Radiology Department, University Hospital Marqués de Valdecilla, 39008 Santander, Spain; \\ franciscojose.gonzalezs@scsalud.es \\ 6 Immunology Department, University Hospital Marqués de Valdecilla, 39008 Santander, Spain \\ * Correspondence: jifortea@gmail.com or joseignacio.fortea@scsalud.es; Tel./Fax: +34-(94)-2202520 (ext. 72929) \\ + These authors contributed equally to this manuscript.
}

Academic Editor: Jordi Gracia-Sancho

Received: 26 July 2020; Accepted: 26 August 2020; Published: 31 August 2020

\begin{abstract}
In patients with liver cirrhosis the contribution of inherited and acquired prothrombotic disorders in the development of non-malignant portal vein thrombosis (PVT) is inconclusive. The purpose of this retrospective study was to examine the prevalence of thrombophilia in this setting at our center from January 2012 to November 2019. Tests included gene mutational analysis for Factor V Leiden, prothrombin G20210A, JAK2 (V617F), Calreticulin (CARL), in addition to activated protein $\mathrm{C}$ resistance, antithrombin III, protein $\mathrm{C}$ and $\mathrm{S}$ levels, and antiphospholipid antibodies. We included 77 patients, six of whom $(7.8 \%)$ had a thrombophilic disorder: antiphospholipid syndrome in four patients, prothrombin gene mutation in one and factor $\mathrm{V}$ Leiden mutation in one. This latter patient had also been diagnosed with polycythemia vera years before PVT development. Complete thrombosis of the main portal vein and re-thrombosis after stopping anticoagulation were more frequent in patients with thrombophilia, but the rates of recanalization under anticoagulant therapy were similar among groups. No other difference was accounted between groups. The low prevalence of acquired and inherited thrombophilia found in patients with cirrhosis and PVT support testing for these disorders on an individual basis and avoiding universal screening to reduce costs and unwarranted testing.
\end{abstract}

Keywords: liver cirrhosis; portal vein thrombosis; thrombophilia

\section{Introduction}

Non-malignant portal vein thrombosis (PVT) is defined as a thrombus that develops within the portal vein trunk and intrahepatic portal branches, which may also involve the splenic (SV) 
or superior mesenteric veins (SMV). In the absence of recanalization, the portal venous lumen is obliterated and portoportal collaterals develop resulting in portal cavernoma. Although the latter transformation can develop very early after acute PVT, it is generally used to define the chronic stage of PVT [1]. It constitutes the most common thrombotic event in patients with cirrhosis, with increased rates in the setting of advanced liver disease. The reported prevalence of PVT varies with different diagnostic methods and target populations, ranging between approximately $10-25 \%$ in patients with decompensated cirrhosis and 1-5\% in those with compensated cirrhosis [2]. Despite being a well-known complication of liver cirrhosis, the contribution of PVT to hepatic decompensation and overall mortality is still a matter of debate [1,3-5]. Discrepancies among studies regarding patient selection criteria (compensated vs. decompensated), degree and extent of thrombosis (occlusive vs. nonocclusive), treatment strategies (anticoagulation vs. no anticoagulation), sample size and time of follow-up have led to conflicting data [6]. There is consequently no consensus on its optimal management and no definitive recommendations have been reported in clinical guidelines or consensus conferences $[1,4,5,7,8]$.

The mechanisms involved in the development of PVT in patients with cirrhosis are also not yet fully understood. Of the three pathophysiologic factors predisposing to thrombosis described in the triad of Virchow (i.e., slow blood flow, endothelial damage and hypercoagulability), portal flow seems to be the most influential in the setting of cirrhosis [4]. The efficacy of transjugular intrahepatic portosystemic shunt (TIPS) in restoring PVT patency by presumably increasing portal flow [1] and the identification of a reduced portal flow as a major risk factor for PVT development support this notion $[9,10]$. Other potential mechanisms involved include a state of hypercoagulability in more advanced disease, bacterial translocation and inflammation, and vascular injury to the portal venous system secondary to several procedures (e.g., splenectomy) [3].

Inherited and acquired prothrombotic disorders may also play a role, although current data are conflicting. The limited number of studies available are mostly case-control studies with small sample sizes. Their study design, target population (diverse ethnicities and geographical locations), diagnostic criteria for PVT, and assessment of thrombophilic conditions vary widely, and contribute to the inconsistent results [11-33]. Moreover, none of these studies have properly evaluated whether the presence of thrombophilia impact the progression rate or response to treatment. Among the different thrombophilic genetic defects, Factor V Leiden (FVL) and prothrombin G20210A (PTHR) mutations have been the most frequently studied. Three meta-analysis concluded that they increased the risk of PVT in patients with cirrhosis [34-36], although in one of them this association was not shown for PTHR [35] and all of them are biased by the quality of the studies included. Inherited protein C, protein $\mathrm{S}$ or antithrombin III deficiencies are difficult to detect due to co-existent liver synthetic dysfunction [4]. Their levels, however, do not seem to be associated with PVT development [37]. The methylene tetrahydrofolate reductase C677T and plasminogen activator inhibitor- type $14 \mathrm{G}-4 \mathrm{G}$ mutations have also been described as independent predictors of PVT [18], although these polymorphisms have not been conclusively associated with increased thrombotic risk [38]. The role of acquired prothrombotic disorders has been less evaluated in patients with liver cirrhosis and PVT. In contrast to non-cirrhotic PVT, the relevance of myeloproliferative disorders and antiphospholipid syndrome (APS) is so far inconclusive [3]. Due to the conflicting data, current guidelines make no strong recommendation regarding testing for these conditions in either a screening capacity before PVT diagnosis, or confirmatory once thrombosis has developed $[1,4,7,8]$.

The main purpose of this study was to examine the prevalence of inherited and acquired thrombophilia in cirrhotic non-malignant PVT at our center and to describe the clinical presentation of PVT in these patients. As a secondary aim we analyzed the course of PVT in the whole cohort and determined the factors associated with PVT recanalization. 


\section{Experimental Section}

\subsection{Patients}

The Marques de Valdecilla University Hospital (Santander, Cantabria, Spain) is an urban, academic tertiary care center. Since 2012 we began to test for thrombophilia in patients with cirrhosis who developed non-malignant PVT. In this report, we conducted a retrospective cohort study regarding the presence and influence on outcomes of inherited and acquired thrombophilia in this setting from January 2012 to November 2019. Patients were mainly selected from the database of our Gastrointestinal and Hepatology Service. To ensure the identification of all eligible patients we also reviewed: (1) all thrombophilic studies performed during the study period by the Department of Hematology; (2) hospital discharge records. This search did not include cases of PVT diagnosed at autopsy.

Cirrhosis was confirmed on the basis of clinical, laboratory, and imaging studies or liver biopsy, and PVT was diagnosed as part of biannual screening for hepatocellular carcinoma (HCC) or during hospitalization for decompensated cirrhosis. Patients without thrombophilic study or with malignant PVT (i.e., presence of vascularization of the thrombus at contrast imaging, mass-forming features of PVT and/or evidence of disruption of vessel walls) were excluded. The presence of a cavernomatous transformation of the portal vein was not considered an exclusion criterion.

\subsection{Definitions}

PVT was defined as the absence of flow in part of or in the entire lumen of any site among portal vein trunk, portal vein branches, superior mesenteric vein (SMV) or splenic vein (SV) caused by the presence of solid material within the vein, as documented by an imaging technique (Doppler ultrasound (US), computed tomography (CT]), or magnetic resonance imaging (MRI)).

\subsubsection{Thrombosis}

Thrombosis was considered complete when the blood flow was absent, or the thrombus involved more than $90 \%$ of the vessel diameter. Otherwise, it was defined as partial. Evolution of thrombosis was classified as previously reported by Delgado et al. [39].

\subsubsection{Recanalization}

Recanalization was considered complete when the portal vein trunk, portal vein branches, SMV, and SV were all completely patent. Recanalization was considered partial when some parts of the thrombus persisted but there was at least a 50\% reduction in the thickness or length of the thrombus, or when complete patency was achieved in the portal vein trunk and in at least one of the following segments if previously thrombosed: main intrahepatic branches, SV or SMV. Lack of recanalization according to the definition above was considered to be a non-response to treatment.

\subsubsection{Thrombosis Progression}

Thrombosis progression was considered to occur when thrombus thickness increased $>50 \%$ or when the thrombosis extended to previously unaffected segments of the spleno-porto-mesenteric axis.

\subsection{Anticoagulation Therapy}

Treatment decisions were at the discretion of the physician taking care of the patient. Appropriate primary or secondary prophylaxis of variceal bleeding was always undertaken before starting anticoagulant treatment. In general, full-dose low-molecular-weight heparin (LMWH) was started and switched after four-six weeks to vitamin $\mathrm{k}$ antagonists to maintain INR between 2 and 3. Patients with significantly prolonged INR in the setting of advanced liver cirrhosis were maintained with LMWH. Among patients receiving LMWH, anti-factor Xa activity (HemosIL liquid Anti Xa) was not routinely performed to verify the efficacy of anticoagulation. 


\subsection{Follow Up}

The date of the first abdominal imaging study detecting PVT was considered as time zero for computing follow-up. Clinical, epidemiological, laboratory, and radiological data were collected at PVT diagnosis. Imaging follow-up was not performed according to a strict protocol, but at the discretion of the attending physicians. In general, it consisted of abdominal US and CT/MRI within 6 months of start of anticoagulation and then abdominal Doppler US every 6 months. The most recent follow-up imaging studies were used to evaluate PVT recanalization if performed at least four weeks after PVT diagnosis. Recurrent thrombosis after recanalization was assessed in those patients that stopped anticoagulation therapy before the end study. All data was extracted from the electronic medical record.

\subsection{Thrombophilic Study}

Test for thrombophilia were delayed until at least four weeks after PVT diagnosis, at which time LMWH were switched to vitamin $\mathrm{K}$ antagonists. Tests included gene mutational analysis for FVL and PTHR, in addition to activated protein C resistance, antithrombin III, protein C and $\mathrm{S}$ levels, and antiphospholipid antibodies. The latter included anticardiolipin (aCL), antibeta2 glycoprotein (aB2GPI), and lupus anticoagulant (LA). Screening of myeloproliferative neoplasms by gene mutational analysis for JAK2 (V617F) and CALR was performed since 2015. The hypercoagulable panel was interpreted by the Hematology department, and the presence of liver cirrhosis was taken into consideration in all patients. Diagnosis of APS and myeloproliferative neoplasms were defined according to the revised Sapporo criteria [40] and the revised WHO classification of myeloid neoplasms [41], respectively.

Blood samples were collected in vacutainer tubes containing NaCitrate $3.2 \%$ in $1 / 9$ proportion. After centrifugation (2500 rpm), $1 \mathrm{~mL}$ aliquots were stored at $-30{ }^{\circ} \mathrm{C}$ and used within 30 days. Protein $\mathrm{C}$ and antithrombin III were determined using automated chromogenic assay for quantitative determination on IL Coagulation Systems (HemosIL Werfen ${ }^{\circledR}$, Instrumentation Laboratory, Bedford, MA, USA). Free Protein $S$ level was determined using an automated latex ligand immunoassay on IL Coagulation Systems (HemosIL Werfen ${ }^{\circledR}$ ). Activated Protein C resistance was determined with coagulometric test based on TTPa parameter (HemosIL Werfen ${ }^{\circledR}$ ). Normal values were established according to 100 control patients of the same age range and gender and were as follows: antithrombin, 85-140\%; protein C, 85-140\%; protein S, 70-120\%. LA was determined using diluted Russell's viper venom test and silica Cotting time (HemosIL Werfen ${ }^{\circledR}$ ). Serum IgG and IgM aCL and aB2GPI levels were measured by ELISA following manufacturer's instructions (Orgentec Diagnostika, Mainz, Germany) and expressed in IgG phospholipid (GPL) or IgM phospholipid (MPL) units or U/mL, respectively. Titers were considered to be positive when they were above the 99th percentile, thus corresponding to values above $20 \mathrm{GPL}, \mathrm{MPL}$ or $\mathrm{U} / \mathrm{mL}$ (medium: 20-30 or high: $>30$ titers). If positive, they were repeated at least 12 weeks later in order to confirm their positivity.

Prothrombin G20210A and FVQ506 mutation were determined using LightCycler ${ }^{\circledR} 2.0$ instrument utilizing polymerase chain reaction (PCR Roche Diagnostics ${ }^{\circledR}$, Roche Diagnostics GmbH, Mannheim, Germany) RNA was extracted from peripheral blood leukocytes and was reverse transcribed with random hexamer primers following standard protocol. Allele-specific standard PCR was performed in a final volume of $50 \mu \mathrm{L}$ using forward primers that were specific for JAK2 V617F Forward 5'-TCCTCAGAACGTTGATGGCAG-3' and Reverse 3'-GTTTTACTTACTCTCGTCTCCACAAAA-3' producing a 279 bp product in positive cases. A positive control was added in each reaction. A control PCR with a Wild type Forward primer was run in parallel to assess the quality of each sample. PCR conditions were $94^{\circ} \mathrm{C}$ for $7 \mathrm{~min} ; 40$ cycles with denaturation at $94^{\circ} \mathrm{C}$ for $30 \mathrm{~s}$, annealing at $60^{\circ} \mathrm{C}$ for $30 \mathrm{~s}$, and elongation at $72{ }^{\circ} \mathrm{C}$ for $30 \mathrm{~s} ; 1$ cycle at $72{ }^{\circ} \mathrm{C}$ for $7 \mathrm{~min}$; and a final hold at $4{ }^{\circ} \mathrm{C}$. Verification of the expected PCR product was performed on a $2 \%$ agarose gel stained with ethidium bromide. All patient specimens that were negative for JAK2 V617F were assessed for CALR mutations on exon 9 using a polymerase chain reaction (PCR)-based assay (forward primer 5'-GGCAAGGCCCTGAGGTGT-3' and 
reverse 5'-GGCCTCAGTCCAGCCCTG-3' PCR; annealing temperature $55^{\circ} \mathrm{C}$ ) producing a $263 \mathrm{bp}$ band on a $2 \%$ agarose gel. Type 1 mutations (c.1092_1143del) were detected on the gel. To detect CALR additional mutations, subsequent sanger deep-sequencing was performed.

The study protocol conformed to the ethical guidelines of the 1975 Declaration of Helsinki as reflected in a priori approval by the Ethics Committee for Clinical Research of Cantabria (internal code: 2020.246). A waiver of informed consent was provided since the study was considered a retrospective review.

\subsection{Statistical Analysis}

Continuous variables were assessed by Kolmogorov-Smirnov test for normality and expressed as mean \pm standard deviation or median and interquartile range. Categorical variables were expressed as counts and percentages. Comparisons between patients with and without thrombophilia were performed using Student's T test or Mann-Whitney U test for continuous variables and $\chi 2$ or Fisher's exact test for categorical variables as applicable. Follow-up was calculated from the time of PVT diagnosis to the date of the last imaging study available before death, liver transplantation, or 1st June 2020. We performed a Cox univariate analysis to explore the variables associated with PVT recanalization (partial or complete). Those variables associated $(p \leq 0.10)$ with PVT recanalization in the univariate analysis or those considered to be clinically significant were tested in a Cox multivariate regression model. We estimated the contribution of each variable by the hazard ratio (HR) with its $95 \%$ confidence interval. $P<0.05$ was considered statistically significant. We limited the number of variables in the multivariable analysis to 1 per 5-10 outcomes. Statistical analysis was performed with IBM SPSS Statistics v22.0 for Mac (IBM Corp., Armonk, NY, USA).

\section{Results}

\subsection{Prevalence of Thrombophilia}

During the study period, 166 cases of PVT were evaluated, of which 89 were excluded (Figure 1). The final cohort included 77 patients with liver cirrhosis and non-malignant PVT in whom a thrombophilic study had been performed. Compared to patients excluded for not having a thrombophilia workup, the patients included were younger (61.9 (55.0-67.6) vs. 70.0 (58.2-77.1), $p=0.003)$, had lower Child (7 (6-9) vs. $13(10-19.5) ; p=0.014)$ and MELD points (12 (10-14) vs. 13 (10-19.5)) and had a lower prevalence of HCC at PVT diagnosis (13\% vs. $32 \% ; p=0.014)$. Screening of JAK2 V617 and CARL mutations was investigated in 37 patients (48.1\%) and antiphospholipid antibodies were not tested in one patient. The remaining thrombophilic tests were available in the whole cohort.

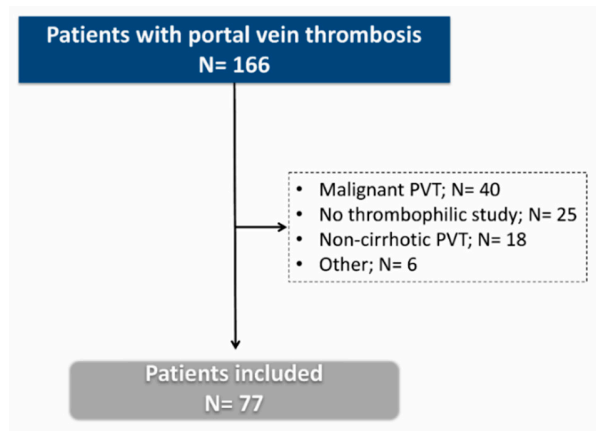

Figure 1. Flowchart of the study selection process. PVT: portal vein thrombosis.

Six patients (7.8\%) had a thrombophilic disorder: antiphospholipid syndrome in four patients, PTHR mutation in one and FVL mutation in one. This latter patient had already been diagnosed with polycythemia vera (JAK2 V617F positive) years before PVT development. A detailed description of these six patients is provided in Table 1. 
Table 1. Clinical, imaging, endoscopic and laboratory features of patients with thrombophilia.

\begin{tabular}{|c|c|c|c|c|c|c|}
\hline Variable * & Case 1 & Case 2 & Case 3 & Case 4 & Case 5 & Case 6 \\
\hline Type of thrombophilia & APS & APS & APS & APS & $\begin{array}{c}\text { PV + FVL } \\
\text { (heterozygous) }\end{array}$ & PTHR (heterozygous \\
\hline Age (years) & 51 & 77 & 57 & 56 & 72 & 69 \\
\hline Gender & Female & Male & Male & Male & Male & Male \\
\hline Race & Caucasian & Caucasian & Caucasian & Caucasian & Caucasian & Caucasian \\
\hline Comorbidity & Diabetes & Diabetes & No & Hypertension & Diabetes & Diabetes \\
\hline Etiology of liver disease & Hepatitis C & Alcohol & Alcohol & Alcohol & Alcohol & Alcohol \\
\hline Child-Pugh & B (7 points) & B (7 points) & A (6 points) & B (9 points) & B (7 points) & A (6 points) \\
\hline MELD (points) & 11 & 9 & 8 & 27 & 13 & 10 \\
\hline Previous decompensation & $\mathrm{VB}+\mathrm{HE}+$ ascites & Ascites & $\mathrm{VB}+$ ascites & Ascites & No & $\mathrm{VB}+\mathrm{HE}+$ ascites \\
\hline EV without bleeding & & High risk & & Low risk & High risk & \\
\hline Non-selective betablockers & Yes & Yes & Yes & Yes & No & Yes \\
\hline $\begin{array}{l}\text { Hepatocellular carcinoma }(\mathrm{HCC}) \\
\text { (No/BCLC stage) }\end{array}$ & No & No & No & No & No & A \\
\hline Previous thrombotic events & No & No & No & No & No & No \\
\hline Imaging for PVT diagnosis & $\mathrm{CT}$ & US & $\mathrm{CT}$ & $\mathrm{CT}$ & US & CT \\
\hline Localization and extension & Main PV/Complete & Main PV/Partial & $\begin{array}{l}\text { Main PV (complete), } \\
\text { SV and SMV (partial) }\end{array}$ & $\begin{array}{l}\text { PV, both branches and } \\
\text { SMV/Partial }\end{array}$ & $\begin{array}{c}\text { PV and } \\
\text { branches/Complete }\end{array}$ & Right PV/Complete \\
\hline Portal cavernoma & Yes & No & No & No & No & No \\
\hline Local predisposing factor & No & No & No & No & No & No \\
\hline Decompensation at diagnosis & Ascites & VB and ascites & No & SBP and HE & Ascites & No \\
\hline $\begin{array}{l}\text { Other symptoms } \\
\text { ontytich }\end{array}$ & No & No & No & No & No & No \\
\hline $\begin{array}{l}\text { Analytical parameters at diagnosis } \\
\text { Leucocytes }(\times 103 \mu \mathrm{L})\end{array}$ & 3.4 & 5.1 & 3.0 & 12.0 & 2.3 & 5.0 \\
\hline Platelets $(\times 103 \mu \mathrm{L})$ & 60 & 140 & 35 & 94 & 65 & 162 \\
\hline Hemoglobin (gr/dL) & 9.8 & 11.6 & 14.8 & 13.8 & 11 & 13.9 \\
\hline Creatinine $(\mathrm{mg} / \mathrm{dL})$ & 0.96 & 0.97 & 0.80 & 2.81 & 0.88 & 0.85 \\
\hline Sodium $(\mathrm{mEq} / \mathrm{L})$ & 138 & 134 & 137 & 129 & 138 & 137 \\
\hline $\operatorname{ALT}(\mathrm{U} / \mathrm{L})$ & 56 & 44 & 20 & 21 & 62 & 26 \\
\hline $\mathrm{AP}(\mathrm{U} / \mathrm{L})$ & 119 & 235 & 46 & 100 & 47 & 123 \\
\hline Bilirubin $(\mathrm{mg} / \mathrm{dL})$ & 0.9 & 1.2 & 0.6 & 3 & 2.1 & 1.4 \\
\hline Albumin $(\mathrm{gr} / \mathrm{dL})$ & 2.9 & 3.2 & 4.4 & 3.4 & 4.2 & 3.8 \\
\hline INR & 1.45 & 1.14 & 1.2 & 1.77 & 1.34 & 1.27 \\
\hline Treatment & Acenocoumarol & Acenocoumarol & Acenocoumarol & Acenocoumarol & LMWH & No \\
\hline PVT evolution & Progression & Partial resolution & No & Total resolution & Total resolution & Stability \\
\hline Duration anticoagulation (months) & Indefinite (157.2) & Finite (8.1) & Indefinite (101.1) & Indefinite (38.6) & (Finite) 22.2 & \\
\hline Re-thrombosis & & Yes & & & Yes & \\
\hline Exitus/LT & $\mathrm{LT}$ & Death & Death & No & Death & $\mathrm{LT}$ \\
\hline Time of follow-up (months) & 21.3 & 16.9 & 102.5 & 38.6 & 85.0 & 24.0 \\
\hline
\end{tabular}

${ }^{*}$ Quantitative variables were expressed as median and interquartile range and qualitative variables as absolute value (proportion). 
Antiphospholipid antibodies were present in 13 patients (16.9\%), but eventually only four were diagnosed with APS once their persistent positivity was confirmed in further tests after 12 weeks. LA and IgM aB2GPI were the most frequent antiphospholipid antibodies (6.6\% and 7.9\%, respectively). Their positivity tended to be more frequent in Child B-C patients in comparison to Child A patients (22.9 vs. $7.4 \%, p=0.118)$. Levels of antithrombin III, protein $S$ and $C$ were decreased in $70(90.9 \%)$, $72(93.5 \%)$ and $44(57.1 \%)$ patients, respectively. These deficiencies were interpreted as secondary to liver cirrhosis and not as an inherited thrombophilia.

\subsection{Characteristics of Patients with and without Thrombophilia}

The clinical and epidemiological profile of patients with and without thrombophilia was similar (Table 2). Most patients had an alcoholic liver disease, were decompensated before PVT diagnosis and were on non-selective betablocker treatment in the setting of primary or secondary prophylaxis of variceal bleeding. Three patients, all in the non-thrombophilic group, had suffered a previous arterial or venous thrombotic event (myocardial infarction in one patient, deep vein thrombosis in another, and pulmonary embolism in the remaining patient). No female patient in either group had a history of pregnancy complications consistent with thrombophilia.

Table 2. Clinical and epidemiological profile of patients in the whole cohort and in patients with and without thrombophilia.

\begin{tabular}{|c|c|c|c|c|}
\hline Variable * & $\begin{array}{l}\text { Population } \\
(\mathbf{N}=77)\end{array}$ & $\begin{array}{l}\text { Non-Thrombophilia } \\
\quad(N=71)\end{array}$ & $\begin{array}{l}\text { Thrombophilia } \\
\qquad(\mathrm{N}=6)\end{array}$ & $p$ \\
\hline Age (years) & $61.9(55.0-67.6)$ & $61.9(54.9-67.2)$ & $63(54.6-73.6)$ & 0.464 \\
\hline Race (Caucasian) & $76(98.7)$ & $70(98.6)$ & $6(100)$ & 1 \\
\hline Diabetes Mellitus & $24(31.2)$ & $20(28.2)$ & $4(66.7)$ & 0.072 \\
\hline Dyslipidemia & $12(15.6)$ & $12(16.9)$ & $0(0)$ & 0.582 \\
\hline HIV & $4(5.2)$ & $4(5.6)$ & $0(0)$ & 1 \\
\hline Etiology of liver disease & & & & 0.969 \\
\hline Alcohol & $49(63.6)$ & $44(62.0)$ & $5(83.3)$ & \\
\hline Hepatitis C & $8(10.4)$ & $7(9.9)$ & $1(16.7)$ & \\
\hline Other & $20(26.0)$ & $20(28.2)$ & $0(0)$ & \\
\hline Liver allograft cirrhosis & $3(3.9)$ & $3(4.2)$ & $0(0)$ & 1 \\
\hline Esophageal varices (Low/High risk) & $14(32) / 22(50)$ & $13(31.7) / 20(48.8)$ & $1(33.3) / 2(66.7)$ & 0.682 \\
\hline Previous variceal bleeding & $33(42.9)$ & $30(42.3)$ & $3(50)$ & 1 \\
\hline Non-selective betablockers & $51(66.2)$ & $46(64.8)$ & $5(83.3)$ & 0.657 \\
\hline Previous ascites (No/Yes/Refractory) (\%) & $27 / 65 / 8$ & $28 / 63 / 9$ & $17 / 83 / 0$ & 0.818 \\
\hline Previous SBP & $6(7.8)$ & $6(8.5)$ & $0(0)$ & 1 \\
\hline Previous HE (No/Episodic/Recurrent) (\%) & $75 / 24 / 1$ & $76 / 23 / 1$ & $67 / 33 / 0$ & 0.808 \\
\hline Any previous decompensation & $62(80.5)$ & $57(80.3)$ & $5(83.3)$ & 1 \\
\hline HCC (No/BCLC stage A/B) (\%) & $87 / 12 / 1$ & $88 / 11 / 1$ & $83 / 17 / 0$ & 0.890 \\
\hline $\begin{array}{l}\text { Previous arterial/venous thrombotic } \\
\text { events }\end{array}$ & $3(3.9)$ & $3(4.2)$ & $0(0)$ & 1 \\
\hline
\end{tabular}

* Quantitative variables were expressed as median and interquartile range and qualitative variables as absolute value (proportion).

\subsection{Extension and Clinical Characteristics of Thrombosis at Diagnosis}

Diagnosis of PVT was made by CT or MRI in the majority of patients. The portal vein or its branches were the only thrombosed vessels in 50 patients $(64.9 \%)$. In two patients $(2.6 \%)$ the thrombosis extended to the SV, in $17(22.1 \%)$ to the SMV, and in four patients (5.2\%) it involved the entire splenoportomesenteric venous axis. Three patients (3.9\%) had isolated thrombosis of the SMV and one $(1.3 \%)$ of the SV. Portal cavernoma was established in nine patients $(11.7 \%)$. In most cases, thrombosis was partial, regardless of its location. In patients with thrombophilia, however, complete 
thrombosis of the main portal vein was more frequent in comparison to patients without thrombophilia (Table 3). Four patients, all in the non-thrombophilic group, had a local predisposing local factor. In all them PVT developed several weeks after radiofrequency ablation of HCC.

Thirty-three patients (42.9\%) showed new symptoms overlapping with the diagnosis of PVT. The most frequent decompensation event was variceal bleeding followed by hepatic encephalopathy. PVT only led to the development of mesenteric ischemia in one patient (1.5\%). No differences in clinical presentation or analytical parameters were observed between patients with and without thrombophilia (Table 3).

Table 3. Extension and clinical characteristic of portal vein thrombosis at diagnosis in the whole cohort and in patients with and without thrombophilia.

\begin{tabular}{|c|c|c|c|c|}
\hline Variable * & $\begin{array}{l}\text { Population } \\
(\mathrm{N}=77)\end{array}$ & $\begin{array}{l}\text { Non-Thrombophilia } \\
\quad(\mathrm{N}=71)\end{array}$ & $\begin{array}{l}\text { Thrombophilia } \\
\qquad(\mathrm{N}=6)\end{array}$ & $p$ \\
\hline $\begin{array}{l}\text { CT or MRI portal vein thrombosis } \\
\text { (PVT) diagnosis }\end{array}$ & $67(87.0)$ & $63(88.7)$ & $4(66.7)$ & 0.172 \\
\hline \multicolumn{5}{|l|}{ Localization and extension } \\
\hline Right PV (Partial/total) (\%) & $27(35.1) / 8(10.4)$ & $26(36.6) / 6(8.5)$ & $1(16.7) / 2(33.3)$ & 0.139 \\
\hline Left PV (Partial/total) (\%) & $18(23.4) / 5(6.5)$ & $16(22.5) / 5(7.0)$ & $2(33.3) / 0(0)$ & 0.701 \\
\hline Main PV (Partial/total) (\%) & $49(63.6) / 8(10.4)$ & $47(66.2) / 5(7.0)$ & $2(33.3) / 3(50)$ & 0.004 \\
\hline Splenic vein (SV) (Partial/total) (\%) & $5(6.5) / 2(2.6)$ & $4(5.6) / 2(2.8)$ & $1(16.7) / 0(0)$ & 0.536 \\
\hline $\begin{array}{l}\text { Superior mesenteric vein (SMV) } \\
(\text { Partial/total) }(\%)\end{array}$ & $21(27.3) / 3(3.9)$ & $19(26.8) / 3(4.2)$ & $2(33.3) / 0(0)$ & 0.841 \\
\hline Portal cavernoma & $9(11.7)$ & $8(11.3)$ & $1(16.7)$ & 0.538 \\
\hline Local predisposing factor & $4(5.2)$ & $4(5.6)$ & $0(0)$ & 1 \\
\hline Symptoms at diagnosis & $33(42.9)$ & $31(43.7)$ & $2(33.3)$ & 0.695 \\
\hline Acute mesenteric ischemia & $1(1.3)$ & $1(1.4)$ & $0(0)$ & 1 \\
\hline Abdominal pain & $7(9.1)$ & $7(9.9)$ & $0(0)$ & 1 \\
\hline Fever & $2(2.6)$ & $2(2.8)$ & $0(0)$ & 1 \\
\hline Variceal bleeding & $14(18.2)$ & $13(18.3)$ & $1(16.7)$ & 1 \\
\hline Ascites (total/de novo) & $38(49.4) / 5(6.5)$ & $34(47.9) / 4(5.6)$ & $4(66.7) / 1(16.7)$ & 0.431 \\
\hline SBP & $6(7.8)$ & $5(7.0)$ & $1(16.7)$ & 0.396 \\
\hline HE & $10(13.0)$ & $9(12.7)$ & $1(16.7)$ & 0.579 \\
\hline \multicolumn{5}{|l|}{ Analytical parameters at diagnosis } \\
\hline Leucocytes $(\times 103 \mu \mathrm{L})$ & $5.0(3.3-6.0)$ & $5.0(3.4-6.0)$ & $4.2(2.8-6.8)$ & 0.791 \\
\hline Platelets $(\times 103 \mu \mathrm{L})$ & $79(62-110)$ & $79(63-109)$ & $80(54-146)$ & 0.882 \\
\hline Hemoglobin (gr/dL) & $12.8(10.4-14.4)$ & $12.8(10.3-14.4)$ & $12.7(10.7-14.1)$ & 0.905 \\
\hline Creatinine (mg/dL) & $0.8(0.7-1.0)$ & $0.8(0.7-1.0)$ & $0.9(0.8-1.4)$ & 0.309 \\
\hline Sodium $(\mathrm{mEq} / \mathrm{L})$ & $139(137-141)$ & 139 (137-141) & $137(132-138)$ & 0.124 \\
\hline $\operatorname{ALT}(\mathrm{U} / \mathrm{L})$ & $34(23-46)$ & $34(24-45)$ & $35(21-58)$ & 0.768 \\
\hline Alkaline phosphatase (U/L) & $114(78-154)$ & $114(79-155)$ & $110(47-151)$ & 0.576 \\
\hline Bilirubin & $1.6(1.1-2.5)$ & $1.6(1.2-2.6)$ & $1.3(0.8-2.3)$ & 0.389 \\
\hline Albumin (gr/dL) & $3.4(3.0-3.8)$ & $3.4(3.0-3.8)$ & $3.6(3.1-4.3)$ & 0.296 \\
\hline INR & $1.34(1.23-1.52)$ & $1.34(1.23-1.52)$ & $1.31(1.19-1.53)$ & 0.691 \\
\hline
\end{tabular}

* Quantitative variables were expressed as median and interquartile range and qualitative variables as absolute value (proportion).

\subsection{Treatment and Factors Associated with the Outcome of Portal Vein Thrombosis}

Five patients from the non-thrombophilic group were excluded from this analysis. Four of them were participating in a randomized control trial to evaluate the effect of rivaroxaban in patients with advanced liver disease with PVT (Tromboxaban; EudraCT Number 2016-003240-37) and the other patient died soon after PVT diagnosis due to septic shock. In the remaining 72 patients, anticoagulation was frequently started $(80.5 \%)$, while TIPS placement was rare $(5.6 \%)$ and always indicated by complications of cirrhosis, and not by PVT progression (Table 4). 
Table 4. Treatment and outcome of portal vein thrombosis in the whole cohort and in patients with and without thrombophilia.

\begin{tabular}{|c|c|c|c|c|}
\hline Variable * & $\begin{array}{l}\text { Population } \\
(\mathrm{N}=72)\end{array}$ & $\begin{array}{l}\text { Non-Thrombophilia } \\
\quad(N=66)\end{array}$ & $\begin{array}{l}\text { Thrombophilia } \\
\quad(\mathrm{N}=6)\end{array}$ & $p$ \\
\hline Anticoagulation & $58(80.6)$ & $53(80.3)$ & $5(83.3)$ & 1 \\
\hline Acenocoumarol & 45 (77.6) & 41 (77.4) & $4(80.0)$ & 0.951 \\
\hline LMWH & $12(20.7)$ & $11(20.8)$ & $1(20.0)$ & \\
\hline Apixaban & $1(1.7)$ & $1(1.9)$ & $0(0)$ & \\
\hline Duration (months) & $12.6(6.2-27.0)$ & $11.6(5.8-20.3)$ & $38.6(15.1-129.1)$ & 0.174 \\
\hline $\begin{array}{c}\text { Transjugular intrahepatic portosystemic } \\
\text { shunt (TIPS) }\end{array}$ & $4(5.6)$ & $4(6.1)$ & $0(0)$ & 1 \\
\hline PVT evolution in non-treated patients & $10(3.9)$ & $9(13.6)$ & $1(16.7)$ & 0.923 \\
\hline Stability & $7(70.0)$ & $6(66.7)$ & $1(100)$ & \\
\hline Progression & $2(20.0)$ & $2(22.2)$ & $0(0)$ & \\
\hline Partial resolution & $1(0.0)$ & $1(11.1)$ & $0(0)$ & \\
\hline Total resolution & $0(0)$ & $0(0)$ & $0(0)$ & \\
\hline $\begin{array}{l}\text { PVT evolution in treated patients } \\
\text { (anticoagulation or TIPS) }\end{array}$ & $62(86.1)$ & $57(86.4)$ & $5(83.3)$ & 0.954 \\
\hline Stability & $14(22.6)$ & $13(22.8)$ & $1(20.0)$ & \\
\hline Progression & $7(11.3)$ & $6(10.5)$ & $1(20.0)$ & \\
\hline Partial resolution & $12(19.4)$ & $11(19.3)$ & $1(20.0)$ & \\
\hline Total resolution & $29(46.8)$ & $27(47.4)$ & $2(40.0)$ & \\
\hline $\begin{array}{l}\text { Re-thrombosis after ceasing } \\
\text { anticoagulation }\end{array}$ & $10(32.3)$ & $8(27.6)$ & $2(100)$ & 0.097 \\
\hline Exitus & $36(50.0)$ & $33(50)$ & $3(50)$ & 1 \\
\hline Liver transplantation & $17(23.6)$ & $15(22.7)$ & $2(33.3)$ & 0.621 \\
\hline Time of follow-up (months) & $27.0(10.9-55.5)$ & $27.0(10.8-55.0)$ & $22.7(18.0-69.7)$ & 0.339 \\
\hline
\end{tabular}

* Quantitative variables were expressed as median and interquartile range and qualitative variables as absolute value (proportion).

Therapy was maintained with LMWH in 12 patients, with vitamin $\mathrm{K}$ antagonists in 45 , and with apixaban in one patient. Median delay from PVT diagnosis to the beginning of anticoagulation treatment was nine days (interquartile range, 0-42 days) and its median duration was 12.6 months (interquartile range, 6.2-27.0). PVT recanalization was similar between patients with and without thrombophilia both in treated and non-treated patients (Table 4).

Duration of anticoagulation was finite in thirty-one patients (53.4\%). After ceasing anticoagulation, re-thrombosis developed in ten patients $(32.3 \%)$, with a trend for this event to occur more frequently in patients with thrombophilia (100\% vs. $27.6 \%$; $p=0.097)$. No other difference regarding treatment and outcome was observed between patients with and without thrombophilia (Table 4).

Regarding variables associated with PVT recanalization, the only variable that remained significant on multivariate analysis was the presence of cavernomatosis, which was associated with a worse PVT outcome (HR (95\% CI): 0.110 (0.014-0.849), $p=0.034)$.

\section{Discussion}

In patients with liver cirrhosis, the contribution of inherited and acquired prothrombotic disorders in the development of non-malignant PVT is inconclusive. The limited available data is hampered by the heterogeneity and small sample size of the studies (Table 5). The present report constitutes one of the largest series on this topic and, contrary to most published studies, includes a thorough thrombophilia workup. The interpretation of the hypercoagulable panel by the Hematology Department is another strength of the present work as many previous studies do not provide information in this regard. Our results show a low prevalence of inherited and acquired thrombophilia in patients with cirrhotic non-malignant PVT and question the utility of universal screening in this setting. 
Table 5. Large studies evaluating the prevalence of acquired and inherited thrombophilia in non-malignant portal vein thrombosis in patients with liver cirrhosis *

\begin{tabular}{|c|c|c|c|c|c|c|c|c|c|c|}
\hline $\begin{array}{l}\text { Author and } \\
\text { Year }\end{array}$ & $\mathbf{N}^{+}$ & $\begin{array}{l}\text { Study Period } \\
\text { And Type }\end{array}$ & Population & PTHR $\ddagger$ & FVL $\ddagger$ & APS $\ddagger$ & JAK2 $\ddagger$ & MTHFR $\ddagger$ & PAI ${ }^{\ddagger}$ & Comments \\
\hline $\begin{array}{l}\text { Mahmoud et al.; } \\
1997 \text { [11] }\end{array}$ & 32 & $\begin{array}{c}\text { NS } \\
\text { Retrospective }\end{array}$ & UK & & $\begin{array}{c}1 / 32 \\
(3.1 \%)\end{array}$ & & & & & $\begin{array}{l}\text { Authors concluded Factor V Leiden (FVL) was not a major contributor } \\
\text { of portal vein thrombosis (PVT). Not all } 32 \text { patients had liver cirrhosis. }\end{array}$ \\
\hline $\begin{array}{l}\text { Amitrano et al.; } \\
2000[12]\end{array}$ & 23 & $\begin{array}{l}\text { 1998-1999 } \\
\text { Case-control }\end{array}$ & Italy & $\begin{array}{c}8 / 23 \\
(34.8 \%)\end{array}$ & $\begin{array}{l}3 / 13 \\
(13 \%)\end{array}$ & NS & & $\begin{array}{c}10 / 23 \\
(43.5 \%)\end{array}$ & & $\begin{array}{l}\text { Prothrombin G20210A (PTHR) and MTHFR were strongly associated } \\
\text { with PVT. ACA in } 4 \% \text { and LA in } 0 \% \text {. No further test to confirm ACA } \\
\text { positivity. }\end{array}$ \\
\hline $\begin{array}{l}\text { Amitrano et al.; } \\
2004[13]\end{array}$ & 79 & $\begin{array}{c}1998-2002 \\
\text { Case-control }\end{array}$ & Italy & $\begin{array}{l}15 / 70 \\
(21.4 \%)\end{array}$ & $\begin{array}{c}8 / 70 \\
(11.4 \%)\end{array}$ & NS & & $\begin{array}{c}15 / 70 \\
(21.4 \%)\end{array}$ & & $\begin{array}{l}\text { ACA IgG and ACA IgM at low levels in PVT and in one above } 40 \mathrm{UI} / \mathrm{L} \text {. } \\
\text { PTHR increased more than fivefold the risk of PVT. }\end{array}$ \\
\hline $\begin{array}{l}\text { Mangia et al.; } \\
2005[16]\end{array}$ & 43 & $\begin{array}{c}1997-1999 \\
\text { Case-control }\end{array}$ & Italy & $2 / 43(4.7 \%)$ & $1 / 43(2.3 \%)$ & & & $\begin{array}{c}9 / 43 \\
(20.9 \%)\end{array}$ & & $\begin{array}{l}\text { PTHR, FVL and MTHFR were evenly distributed among patients with } \\
\text { and without PVT. }\end{array}$ \\
\hline $\begin{array}{l}\text { Amitrano et al.; } \\
2006 \text { [14] }\end{array}$ & 78 & $\begin{array}{c}1998-2002 \\
\text { Case-control }\end{array}$ & Italy & $\begin{array}{c}17 / 78 \\
(21.4 \%)\end{array}$ & & & & & & $\begin{array}{l}\text { PTHR was associated with PVT, and factor II levels were higher in } \\
\text { patients with PTHR and PVT. }\end{array}$ \\
\hline $\begin{array}{l}\text { Pasta et al.; } 2006 \\
\text { [17] }\end{array}$ & 78 & $\begin{array}{l}\text { 2000-2005 } \\
\text { Case-control }\end{array}$ & Italy & & & & & $\begin{array}{c}19 / 78 \\
(24.4 \%)\end{array}$ & & MTHFR was associated with PVT development. \\
\hline $\begin{array}{l}\text { Colaizzo et al.; } \\
2008 \text { [19] }\end{array}$ & 91 & $\begin{array}{c}\text { NS } \\
\text { Retrospective }\end{array}$ & Italy & & & & $\begin{array}{c}5 / 91 \\
(5.5 \%)\end{array}$ & & & $\begin{array}{l}\text { Authors suggested to search for } J A K 2 \text { in the setting of severe PVT, } \\
\text { previous thrombosis and no thrombopenia. }\end{array}$ \\
\hline $\begin{array}{l}\text { Gabr et al.; } 2010 \\
\text { [20] }\end{array}$ & 21 & $\begin{array}{c}\text { NS } \\
\text { Case-control }\end{array}$ & Egypt & & & & & $7 / 21(33 \%)$ & & $\begin{array}{l}\text { Authors concluded that MTHFR was associated with an increased risk } \\
\text { of PVT. }\end{array}$ \\
\hline $\begin{array}{l}\text { Amitrano et al.; } \\
2011 \text { [15] }\end{array}$ & 50 & $\begin{array}{c}\text { NS } \\
\text { Case-control }\end{array}$ & Italy & & & $\begin{array}{l}0 / 50 \\
(0 \%)\end{array}$ & & & & $\begin{array}{l}\text { Antiphospholipid antibodies played no role in PVT associated with liver } \\
\text { cirrhosis. }\end{array}$ \\
\hline $\begin{array}{l}\text { Ayala et al.; } 2012 \\
\text { [21] }\end{array}$ & 50 & $\begin{array}{c}\text { 2001-2006 } \\
\text { Case-control }\end{array}$ & Spain & $\begin{array}{l}1 / 49 \\
(2 \%)\end{array}$ & $\begin{array}{l}1 / 49 \\
(2 \%)\end{array}$ & & $\begin{array}{l}0 / 50 \\
(0 \%)\end{array}$ & $\begin{array}{c}7 / 48 \\
(14.6 \%)\end{array}$ & & $\begin{array}{l}\text { No association was observed between pre-transplant PVT and presence } \\
\text { of genetic thrombophilia. }\end{array}$ \\
\hline $\begin{array}{l}\text { Delgado et al.; } \\
2012[39]\end{array}$ & 43 & $\begin{array}{l}\text { 2003-2010 } \\
\text { Retrospective }\end{array}$ & Spain & $\begin{array}{l}3 / 43 \\
(7 \%)\end{array}$ & $\begin{array}{l}1 / 43 \\
(2.3 \%)\end{array}$ & $\begin{array}{c}1 / 43 \\
(2.3 \%)\end{array}$ & & & & $\begin{array}{l}\text { Multicenter study. Thrombophilia in } 16 \% \text { of patients and it was not } \\
\text { associated with response to anticoagulation. }\end{array}$ \\
\hline $\begin{array}{l}\text { Qi et al.; } \\
2012[22]\end{array}$ & 71 & $\begin{array}{l}2009-2011 \\
\text { Prospective }\end{array}$ & China & & & & $\begin{array}{c}1 / 71 \\
(1.4 \%)\end{array}$ & & & $\begin{array}{l}\text { Prevalence very close to that of a Chinese hospital population of patients } \\
\text { without PVT. }\end{array}$ \\
\hline $\begin{array}{l}\text { Senzolo et al.; } \\
2012[23]\end{array}$ & 56 & $\begin{array}{l}\text { 2007-2008 } \\
\text { Prospective }\end{array}$ & UK, Italy & $\begin{array}{l}4 / 56 \\
(7 \%)\end{array}$ & $\begin{array}{c}2 / 56 \\
(3.6 \%)\end{array}$ & $\begin{array}{l}0 / 56 \\
(0 \%)\end{array}$ & - & - & - & Bicenter study. One patient had combined thrombophilia (FVL + PTHR). \\
\hline $\begin{array}{l}\text { Werner et al.; } \\
2013[24]\end{array}$ & 69 & $\begin{array}{l}2005-2011 \\
\text { Retrospective }\end{array}$ & USA & $\begin{array}{l}0 / 22 \\
(0 \%)\end{array}$ & $\begin{array}{l}0 / 22 \\
(0 \%)\end{array}$ & $\begin{array}{l}0 / 22 \\
(0 \%)\end{array}$ & & & & One patient had antithrombin deficiency. \\
\hline $\begin{array}{l}\text { Karakose et al.; } \\
2015[26]\end{array}$ & 38 & $\begin{array}{l}2005-2009 \\
\text { Prospective }\end{array}$ & Turkey & $\begin{array}{c}4 / 38 \\
(10.5 \%)\end{array}$ & $\begin{array}{c}5 / 38 \\
(13.1 \%)\end{array}$ & & $\begin{array}{c}1 / 38 \\
(2.6 \%)\end{array}$ & $\begin{array}{c}5 / 38 \\
(13.2 \%)\end{array}$ & & Unicenter study. \\
\hline $\begin{array}{l}\text { Nery et al.; } 2015 \\
{[25]}\end{array}$ & 67 & $\begin{array}{l}2000-2006 \\
\text { RCT }\end{array}$ & France & NS & NS & & & & & $\begin{array}{l}\text { Multicenter RCT. PTHR and FVL were studied in } 283 \text { patients, (PVT in } \\
\text { 67). Their presence was not associated with PVT. }\end{array}$ \\
\hline $\begin{array}{l}\text { Saugel et al.; } \\
2015 \text { [27] }\end{array}$ & 21 & $\begin{array}{c}2009-2011 \\
\text { Case-control }\end{array}$ & Germany & $\begin{array}{l}0 / 21 \\
(0 \%)\end{array}$ & $\begin{array}{c}1 / 21 \\
(4.8 \%)\end{array}$ & & $\begin{array}{c}2 / 21 \\
(9.5 \%)\end{array}$ & & & $\begin{array}{l}\text { There was a trend for higher frequency of } J A K 2 \text { mutation in cirrhotic } \\
\text { patients with PVT than those without PVT. }\end{array}$ \\
\hline $\begin{array}{l}\text { Lancelloti et al.; } \\
2016[28]\end{array}$ & 24 & $\begin{array}{c}2013 \\
\text { Case-control }\end{array}$ & Italy & $\begin{array}{c}1 / 24 \\
(4.2 \%)\end{array}$ & $\begin{array}{l}0 / 24 \\
(0 \%)\end{array}$ & NS & & & & $\begin{array}{l}\text { PTHR and FVL were infrequent and not associated with PVT } \\
\text { development. }\end{array}$ \\
\hline $\begin{array}{l}\text { Pasta et al.; } 2016 \\
\text { [18] }\end{array}$ & 350 & $\begin{array}{l}\text { 2000-2014 } \\
\text { Prospective }\end{array}$ & Italy & $\begin{array}{c}18 / 350 \\
(5 \%)\end{array}$ & $\begin{array}{c}29 / 350 \\
(8 \%)\end{array}$ & & & $\begin{array}{l}88 / 350 \\
(25 \%)\end{array}$ & $\begin{array}{c}111 / 350 \\
(31 \%)\end{array}$ & $\begin{array}{l}\text { Data from } 3 \text { prospective studies. } \geq 1 \text { genetic thrombophilia in } 54 \% \text { of } \\
\text { patients. MTHFR/PAI were associated with PVT. }\end{array}$ \\
\hline
\end{tabular}


Table 5. Cont

\begin{tabular}{|c|c|c|c|c|c|c|c|c|c|c|}
\hline $\begin{array}{l}\text { Author and } \\
\text { Year }\end{array}$ & $\mathbf{N}^{+}$ & $\begin{array}{l}\text { Study Period } \\
\text { And Type }\end{array}$ & Population & PTHR $\ddagger$ & FVL $\ddagger$ & APS $\ddagger$ & JAK2 $\ddagger$ & MTHFR ‡ & PAI ${ }^{\ddagger}$ & Comments \\
\hline $\begin{array}{l}\text { Ventura et al.; } \\
2016[29]\end{array}$ & 38 & $\begin{array}{c}2009-2013 \\
\text { Case-control }\end{array}$ & Italy & $\begin{array}{c}11 / 38 \\
(10.5 \%)\end{array}$ & $\begin{array}{c}4 / 38 \\
(10.5 \%)\end{array}$ & $\begin{array}{c}2 / 38 \\
(7.9 \%)\end{array}$ & & $\begin{array}{l}13 / 38 \\
(34.2)\end{array}$ & & $\begin{array}{l}\text { PTHR and hyperhomocysteinemia were associated with PVT } \\
\text { development. }\end{array}$ \\
\hline $\begin{array}{l}\text { Artaza et al.; } \\
2018[30]\end{array}$ & 32 & $\begin{array}{l}2009-2015 \\
\text { Retrospective }\end{array}$ & Spain & $\begin{array}{l}0 / 24 \\
(0 \%)\end{array}$ & $\begin{array}{c}2 / 24 \\
(8.3 \%)\end{array}$ & & $\begin{array}{c}1 / 24 \\
(4.2 \%)\end{array}$ & & & $\begin{array}{l}\text { Thrombophilia in } 4 \text { patients (16\%). No association between } \\
\text { thrombophilia and evolution of PVT. }\end{array}$ \\
\hline $\begin{array}{l}\text { Senzolo et al.; } \\
2018 \text { [31] }\end{array}$ & 149 & $\begin{array}{l}\text { 2008-2012 } \\
\text { Prospective }\end{array}$ & International & $\begin{array}{c}7 / 64 \\
(10.9 \%)\end{array}$ & $\begin{array}{c}7 / 71 \\
(9.9 \%)\end{array}$ & & $\begin{array}{l}1 / 32 \\
(3.1 \%)\end{array}$ & & & $\begin{array}{l}\text { Thrombophilia testing }<50 \% \text { of the patients. Authors did not search for } \\
\text { an association between PVT and thrombophilia. }\end{array}$ \\
\hline $\begin{array}{l}\text { Cagin et al.; } \\
2019[32]\end{array}$ & 98 & $\begin{array}{l}2009-2015 \\
\text { Case-control }\end{array}$ & Turkey & $\begin{array}{l}15 / 98 \\
(15.3 \%)\end{array}$ & $\begin{array}{c}12 / 98 \\
(12.2 \%)\end{array}$ & & & $\begin{array}{c}16 / 98 \\
(16.3 \%)\end{array}$ & & FVL mutation was the only type of thrombophilia associated with PVT. \\
\hline $\begin{array}{l}\text { Tremblay et al., } \\
2020[33]\end{array}$ & 73 & $\begin{array}{l}\text { 2000-2019 } \\
\text { Retrospective }\end{array}$ & USA & $\begin{array}{l}4 / 63 \\
(6.3 \%)\end{array}$ & $\begin{array}{c}4 / 65 \\
(6.1 \%)\end{array}$ & $\begin{array}{l}2 / 66 \\
(3 \%)\end{array}$ & $\begin{array}{c}1 / 45 \\
(2.2 \%)\end{array}$ & $\begin{array}{l}1 / 27 \\
(3.7 \%)\end{array}$ & $\begin{array}{c}20 / 34 \\
(58.8 \%)\end{array}$ & $\begin{array}{l}\text { Thrombophilia testing was not complete in most patients and } \\
\text { infrequently led to change in management. }\end{array}$ \\
\hline
\end{tabular}

study, not to the total cohort in each of them. $¥$ Percentages are calculated based on the number of patients tested for each type of thrombophilia, not the total cohort. 
APS was the most common thrombophilic disorder found in our cohort (5.3\%). Similar figures have been observed in some $[29,33]$, but not all studies [15,23,24,39]. These discrepancies might be explained not only by differences in study design or target population, but also by a low adherence to the revised APS criteria [40]. Indeed, many studies performed antiphospholipid-antibody testing only once and cutoffs varied among them. Their clinical significance in the setting of cirrhosis, however, is unclear as antiphospholipid-antibody positivity can be frequently found in patients with liver disease without any evidence of venous thrombosis. This has been regarded as an epiphenomenon of chronic liver injury, and in line with this premise a recent meta-analysis did not find a clear association between the presence of antiphospholipid antibodies and development of PVT in patients with liver cirrhosis [42]. These findings together with the frequently reduced levels of antithrombin III, protein $S$ and $C$ encountered in patients with liver disease (in our cohort $90.9 \%, 93.5 \%$ and $57.1 \%$, respectively) highlight the difficult assessment of the hypercoagulable panel in the setting of cirrhosis and the need for this assessment to be performed by the Hematology Department. The presence of inherited thrombophilia was limited to two patients (2.6\%). These figures are not higher than those described for these disorders in the general population [43]. Finally, the infrequent presence of myeloproliferative neoplasm $(2.7 \%)$ is in line with previous studies in this setting $[21,22,26,31,33]$. Overall, our data show a low prevalence of thrombophilia, either inherited or acquired, which is in agreement with other previous reports that did not find an association between the presence of thrombophilia and the risk of PVT in patients with liver cirrhosis [11,16,21,22,24,27,28,30,33,39].

Regarding the influence of these disorders on the clinical presentation of PVT and response to anticoagulation, complete thrombosis of the main portal vein and re-thrombosis after stopping anticoagulation were more frequent in patients with thrombophilia. In contrast, the rates of recanalization under anticoagulant therapy were similar among groups and in keeping with those reported to date [44]. The low number of patients with thrombophilia limits the significance of these findings and call for larger studies to properly address these issues. While awaiting further evidence, the currently available data along with associated healthcare costs support performing these tests on an individual basis. As in patients with venous thromboembolic disease [43], it is not possible to give a validated recommendation on how such patients should be selected for testing. Our current strategy limits the screening for patients with family histories of prothrombotic defects, patients with multiple sites of thrombosis, recurrent thrombosis, or when treatment decisions (i.e., anticoagulation duration) may be affected.

The main limitations of our study are its retrospective unicenter design and its relatively small sample size, which may limit the external validity of our results and undermine the power to assess the factors associated with PVT recanalization. The exclusion of a significant number of patients without a thrombophilic study who differed in relevant clinical variables from the study population may further introduce a selection bias. We do believe, however, that most of these exclusions are due to a progressive adherence of physicians to conducting a thrombophilic study in this setting. Thus, $76 \%$ of these exclusions involve PVT cases that were diagnosed during the first three years of the implementation of the study protocol. The absence of a control group of patients with cirrhosis but without PVT should also be acknowledged. Nonetheless, the overall interpretation of our results would probably not change given the low prevalence of thrombophilic disorders found in our cohort. This low prevalence makes the influence of thrombophilia on the outcome of PVT unreliable to evaluate. Finally, JAK2 and CALR mutations were not performed in all patients as these tests were later included in the thrombophilia workup. Of note, the PCR used in this study did not allow the quantitation of the allelic burden nor was able to detect low burden cases (below around 5\%). Investigation of the allelic burden with more sensitive techniques such as digital PCR provides more information in this regard. Moreover, investigation of additional somatic variants in JAK2, in other myeloproliferative associated genes such as MPL or in genes involved in the age and clonal hematopoiesis that have been associated with an increased risk of cardiovascular disease, particularly in DNMT3A, TET2, and ASXL1, could have provided more valuable data [45]. 


\section{Conclusions}

We found a low prevalence of acquired and inherited thrombophilia in patients with cirrhosis and PVT. Our results support testing for these disorders on an individual basis and avoiding universal screening to reduce costs and unwarranted testing. Future prospective studies integrating evaluation of liver disease stage, local and genetic factors are needed to identify individualized criteria to perform these tests and to evaluate their impact on the progression rate or response to treatment.

Author Contributions: Conceptualization: J.I.F., I.G.C., Á.P., A.C. and E.F.; Methodology: all authors; Data extraction: J.I.F., I.G.C., C.Á.T., P.Á.F., Á.P., A.C., P.H.; Formal analysis: J.I.F., I.G.C., Á.P., A.C. and E.F.; Writing—original draft preparation: J.I.F., I.G.C., Á.P., A.C., M.d.R.P.M. and E.F.; writing-review and editing: all authors. Funding acquisition: J.I.F. All authors have read and agreed to the published version of the manuscript.

Funding: This study was supported by the Health Research Institute Marqués de Valdecilla. IDIVAL. Santander. NEXT VAL17/07 grant to José Ignacio Fortea Ormaechea.

Conflicts of Interest: The authors declare no conflict of interest.

\section{Abbreviations}

$\begin{array}{ll}\text { ACA } & \text { Anti-cardiolipin antibodies } \\ \text { ALT } & \text { Alanine aminotransferase } \\ \text { AP } & \text { Alkaline phosphatase } \\ \text { APS } & \text { Antiphospholipid syndrome } \\ \text { AT-III } & \text { Antithrombin III } \\ \text { BCLC } & \text { Barcelona Clinic Liver Cancer } \\ \text { CT } & \text { Computed tomography } \\ \text { EV } & \text { Esophageal varices } \\ \text { FV } & \text { factor V Leiden mutation } \\ \text { FVL } & \text { Factor V Leiden } \\ \text { HCC } & \text { Hepatocellular carcinoma } \\ \text { HE } & \text { Hepatic encephalopathy } \\ \text { HIV } & \text { Human immunodeficiency virus } \\ \text { INR } & \text { International normalized ratio } \\ \text { JAK2 } & \text { Janus Kinase 2 mutation } \\ \text { LA } & \text { Lupus anticoagulant } \\ \text { LMWH } & \text { Molecular-weight heparin } \\ \text { LT } & \text { Liver transplantation } \\ \text { MELD } & \text { Model for End-Stage Disease } \\ \text { MRI } & \text { Magnetic resonance imaging } \\ \text { MTHFR } & \text { Methylenetetrahydrofolate reductase TT677 genotype } \\ \text { PAI-1 } & \text { Plasminogen activator inhibitor type 1 } \\ \text { PNH } & \text { Paroxysmal nocturnal hemoglobinuria } \\ \text { PTHR } & \text { Prothrombin G20210A mutation } \\ \text { PV } & \text { Polycythemia vera } \\ \text { PVT } & \text { Portal vein thrombosis } \\ \text { RCT } & \text { Randomized control trial } \\ \text { SBP } & \text { Spontaneous bacterial peritonitis } \\ \text { SMV } & \text { Superior mesenteric vei } \\ \text { SV } & \text { Splenic vein } \\ \text { TIPS } & \text { Transjugular intrahepatic portosystemic shunt } \\ \text { UK } & \text { United Kingdom } \\ \text { US } & \text { Ultrasound } \\ \text { VB } & \text { Variceal bleeding } \\ & \end{array}$




\section{References}

1. EASL Clinical Practice Guidelines: Vascular diseases of the liver. J. Hepatol. 2016, 64, 179-202. [CrossRef]

2. Zanetto, A.; Rodriguez-Kastro, K.I.; Germani, G.; Ferrarese, A.; Cillo, U.; Burra, P.; Senzolo, M. Mortality in liver transplant recipients with portal vein thrombosis-An updated meta-analysis. Transpl. Int. 2018, 31, 1318-1329. [CrossRef]

3. Intagliata, N.M.; Caldwell, S.H.; Tripodi, A. Diagnosis, Development, and Treatment of Portal Vein Thrombosis in Patients with and Without Cirrhosis. Gastroenterology 2019, 156, 1582-1599. [CrossRef]

4. Intagliata, N.M.; Argo, C.K.; Stine, J.G.; Lisman, T.; Caldwell, S.H.; Violi, F. Concepts and Controversies in Haemostasis and Thrombosis Associated with Liver Disease: Proceedings of the 7th International Coagulation in Liver Disease Conference. Thromb. Haemost. 2018, 118, 1491-1506. [CrossRef]

5. O'Leary, J.G.; Greenberg, C.S.; Patton, H.M.; Caldwell, S.H. AGA Clinical Practice Update: Coagulation in Cirrhosis. Gastroenterology 2019, 157, 34-43. [CrossRef]

6. Zanetto, A.; Garcia-Tsao, G. Some Answers and More Questions About Portal Vein Thrombosis in Patients with Decompensated Cirrhosis. Clin. Gastroenterol. Hepatol. 2020, 30485-30487. [CrossRef]

7. DeLeve, L.D.; Valla, D.C.; Garcia-Tsao, G. Vascular disorders of the liver. Hepatology 2009, 49, $1729-1764$. [CrossRef] [PubMed]

8. Martín-Llahí, M.; Albillos, A.; Bañares, R.; Berzigotti, A.; García-Criado, M.; Genescà, J.; Hernández-Gea, V.; Llop-Herrera, E.; Masnou-Ridaura, H.; Mateo, J.; et al. Vascular diseases of the liver. Clinical Guidelines from the Catalan Society of Digestology and the Spanish Association for the Study of the Liver. Gastroenterol. Hepatology 2017, 40, 538-580. [CrossRef]

9. Zocco, M.A.; Di Stasio, E.; De Cristofaro, R.; Novi, M.; Ainora, M.E.; Ponziani, F.; Riccardi, L.; Lancellotti, S.; Santoliquido, A.; Flore, R.; et al. Thrombotic risk factors in patients with liver cirrhosis: Correlation with MELD scoring system and portal vein thrombosis development. J. Hepatol. 2009, 51, 682-689. [CrossRef]

10. Stine, J.G.; Wang, J.; Shah, P.M.; Argo, C.K.; Intagliata, N.; Uflacker, A.; Caldwell, S.H.; Northup, P.G. Decreased portal vein velocity is predictive of the development of portal vein thrombosis: A matched case-control study. Liver. Int. 2018, 38, 94-101. [CrossRef]

11. Mahmoud, A.E.; Elias, E.; Beauchamp, N.; Wilde, J.T. Prevalence of the factor V Leiden mutation in hepatic and portal vein thrombosis. Gut 1997, 40, 798-800. [CrossRef] [PubMed]

12. Amitrano, L.; Brancaccio, V.; Guardascione, M.A.; Margaglione, M.; Iannaccone, L.; D'Andrea, G.; Marmo, R.; Ames, P.R.; Balzano, A. Inherited coagulation disorders in cirrhotic patients with portal vein thrombosis. Hepatology 2000, 31, 345-348. [CrossRef] [PubMed]

13. Amitrano, L.; Guardascione, M.A.; Brancaccio, V.; Margaglione, M.; Manguso, F.; Iannaccone, L.; Grandone, E.; Balzano, A. Risk factors and clinical presentation of portal vein thrombosis in patients with liver cirrhosis. J. Hepatol. 2004, 40, 736-741. [CrossRef]

14. Amitrano, L.; Guardascione, M.A.; Ames, P.R.; Margaglione, M.; Iannaccone, L.; Brancaccio, V.; Balzano, A. Increased plasma prothrombin concentration in cirrhotic patients with portal vein thrombosis and prothrombin G20210A mutation. Thromb. Haemost. 2006, 95, 221-223. [CrossRef]

15. Amitrano, L.; Ames, P.R.; Guardascione, M.A.; Lopez, L.R.; Menchise, A.; Brancaccio, V.; Iannaccone, L.; Balzano, A. Antiphospholipid antibodies and antiphospholipid syndrome: Role in portal vein thrombosis in patients with and without liver cirrhosis. Clin. Appl. Thromb. Hemost. 2011, 17, 367-370. [CrossRef] [PubMed]

16. Mangia, A.; Villani, M.R.; Cappucci, G.; Santoro, R.; Ricciardi, R.; Facciorusso, D.; Leandro, G.; Caruso, N.; Andriulli, A. Causes of portal venous thrombosis in cirrhotic patients: The role of genetic and acquired factors. Eur. J. Gastroenterol. Hepatol. 2005, 17, 745-751. [CrossRef]

17. Pasta, L.; Marrone, C.; D'Amico, M.; Virdone, R.; D'Amico, G.; Sammarco, P.; Fabiano, C.; Pagliaro, L. MTHFR C677T mutations in liver cirrhosis with and without portal vein thrombosis. Liver. Int. 2006, 26, $269-270$. [CrossRef] [PubMed]

18. Pasta, L.; Pasta, F.; D'Amico, M. PAI-1 4G-4G, MTHFR 677TT, V Leiden 506Q, and Prothrombin 20210A in Splanchnic Vein Thrombosis: Analysis of Individual Patient Data from Three Prospective Studies. J. Clin. Exp. Hepatol. 2016, 6, 10-14. [CrossRef]

19. Colaizzo, D.; Amitrano, L.; Guardascione, M.A.; Balzano, A.; Margaglione, M. Janus kinase-2 mutation, cirrhosis and splanchnic vein thrombosis. Eur. J. Gastroenterol. Hepatol. 2008, 20, 245-246. [CrossRef] 
20. Gabr, M.A.; Bessa, S.S.; El-Zamarani, E.A. Portal vein thrombosis in Egyptian patients with liver cirrhosis: Role of methylenetetrahydrofolate reductase C677T gene mutation. Hepatol. Res. 2010, 40, 486-493. [CrossRef]

21. Ayala, R.; Grande, S.; Bustelos, R.; Ribera, C.; García-Sesma, A.; Jimenez, C.; Moreno, E.; Martínez-López, J. Obesity is an independent risk factor for pre-transplant portal vein thrombosis in liver recipients. BMC Gastroenterol. 2012, 12, 114. [CrossRef] [PubMed]

22. Qi, X.; Zhang, C.; Han, G.; Zhang, W.; He, C.; Yin, Z.; Liu, Z.; Bai, W.; Li, R.; Bai, M.; et al. Prevalence of the JAK2V617F mutation in Chinese patients with Budd-Chiari syndrome and portal vein thrombosis: A prospective study. J. Gastroenterol. Hepatol. 2012, 27, 1036-1043. [CrossRef]

23. Senzolo, M.; Sartori, T.M.; Rossetto, V.; Burra, P.; Cillo, U.; Boccagni, P.; Gasparini, D.; Miotto, D.; Simioni, P.; Tsochatzis, E.; et al. Prospective evaluation of anticoagulation and transjugular intrahepatic portosystemic shunt for the management of portal vein thrombosis in cirrhosis. Liver. Int. 2012, 32, 919-927. [CrossRef] [PubMed]

24. Werner, K.T.; Sando, S.; Carey, E.J.; Vargas, H.E.; Byrne, T.J.; Douglas, D.D.; Harrison, M.E.; Rakela, J.; Aqel, B.A. Portal vein thrombosis in patients with end stage liver disease awaiting liver transplantation: Outcome of anticoagulation. Dig. Dis. Sci. 2013, 58, 1776-1780. [CrossRef]

25. Nery, F.; Chevret, S.; Condat, B.; de Raucourt, E.; Boudaoud, L.; Rautou, P.-E.; Plessier, A.; Roulot, D.; Chaffaut, C.; Bourcier, V.; et al. Causes and consequences of portal vein thrombosis in 1,243 patients with cirrhosis: Results of a longitudinal study. Hepatology 2015, 61, 660-667. [CrossRef] [PubMed]

26. Karaköse, S.; Oruç, N.; Zengin, M.; Akarca, U.S.; Ersöz, G. Diagnostic value of the JAK2 V617F mutation for latent chronic myeloproliferative disorders in patients with Budd-Chiari syndrome and/or portal vein thrombosis. Turk. J. Gastroenterol. 2015, 26, 42-48. [CrossRef] [PubMed]

27. Saugel, B.; Lee, M.; Feichtinger, S.; Hapfelmeier, A.; Schmid, R.M.; Siveke, J.T. Thrombophilic factor analysis in cirrhotic patients with portal vein thrombosis. J. Thromb. Thrombol. 2015, 40, 54-60. [CrossRef]

28. Lancellotti, S.; Basso, M.; Veca, V.; Sacco, M.; Riccardi, L.; Pompili, M.; De Cristofaro, R. Presence of portal vein thrombosis in liver cirrhosis is strongly associated with low levels of ADAMTS-13: A pilot study. Intern. Emerg. Med. 2016, 11, 959-967. [CrossRef]

29. Ventura, P.; Venturelli, G.; Marcacci, M.; Fiorini, M.; Marchini, S.; Cuoghi, C.; Pietrangelo, A. Hyperhomocysteinemia and MTHFR C677T polymorphism in patients with portal vein thrombosis complicating liver cirrhosis. Thromb. Res. 2016, 141, 189-195. [CrossRef]

30. Artaza, T.; Lopes, M.; Romero, M.; Gómez, A.Z.; de la Cruz, G.; Sánchez, J.J.; González, C.; Gómez, R. Efficacy and safety of anticoagulation in non-malignant portal vein thrombosis in patients with liver cirrhosis. Gastroenterol. Hepatol. 2018, 41, 611-617. [CrossRef]

31. Senzolo, M.; Riva, N.; Dentali, F.; Rodriguez-Castro, K.; Sartori, M.T.; Bang, S.M.; Martinelli, I.; Schulman, S.; Alatri, A.; Beyer-Westendorf, J.; et al. Long-Term Outcome of Splanchnic Vein Thrombosis in Cirrhosis. Clin. Transl. Gastroenterol. 2018, 9, 176. [CrossRef] [PubMed]

32. Cagin, Y.F.; Bilgic, Y.; Berber, İ.; Yildirim, O.; Erdogan, M.A.; Firat, F.; Arslan, A.K.; Colak, C.; Seckin, Y.; Harputluoglu, M. The risk factors of portal vein thrombosis in patients with liver cirrhosis. Exp. Ther. Med. 2019, 17, 3189-3194. [CrossRef] [PubMed]

33. Tremblay, D.; Naymagon, L.; Troy, K.; Cromwell, C.; Edwards, C.; Schiano, T.; Kremyanskaya, M.; Mascarenhas, J. The utility of thrombophilia testing in patients with newly diagnosed portal vein thrombosis. Blood Coagul. Fibrinolysis 2020, 31, 213-218. [CrossRef] [PubMed]

34. Dentali, F.; Galli, M.; Gianni, M.; Ageno, W. Inherited thrombophilic abnormalities and risk of portal vein thrombosis. a meta-analysis. Thromb. Haemost. 2008, 99, 675-682. [CrossRef]

35. Qi, X.; Ren, W.; De Stefano, V.; Fan, D. Associations of coagulation factor V Leiden and prothrombin G20210A mutations with Budd-Chiari syndrome and portal vein thrombosis: A systematic review and meta-analysis. Clin. Gastroenterol. Hepatol. 2014, 12, 1801-1812. [CrossRef]

36. Ma, S.D.; Wang, J.; Bezinover, D.; Kadry, Z.; Northup, P.G.; Stine, J.G. Inherited thrombophilia and portal vein thrombosis in cirrhosis: A systematic review and meta-analysis. Res. Pract. Thromb. Haemost. 2019, 3 , 658-667. [CrossRef]

37. Qi, X.; Chen, H.; Han, G. Effect of antithrombin, protein C and protein S on portal vein thrombosis in liver cirrhosis: A meta-analysis. Am. J. Med. Sci. 2013, 346, 38-44. [CrossRef]

38. Colucci, G.; Tsakiris, D.A. Thrombophilia screening revisited: An issue of personalized medicine. J. Thromb. Thrombol. 2020, 49, 618-629. [CrossRef] 
39. Delgado, M.G.; Seijo, S.; Yepes, I.; Achécar, L.; Catalina, M.V.; García-Criado, A.; Abraldes, J.G.; de la Peña, J.; Bañares, R.; Albillos, A.; et al. Efficacy and safety of anticoagulation on patients with cirrhosis and portal vein thrombosis. Clin. Gastroenterol. Hepatol. 2012, 10, 776-783. [CrossRef]

40. Miyakis, S.; Lockshin, M.D.; Atsumi, T.; Branch, D.W.; Brey, R.L.; Cervera, R.; Derksen, R.H.W.M.; De Groot, P.G.; Koike, T.; Meroni, P.L.; et al. International consensus statement on an update of the classification criteria for definite antiphospholipid syndrome (APS). J. Thromb. Haemost. 2006, 4, 295-306. [CrossRef]

41. Arber, D.A.; Orazi, A.; Hasserjian, R.; Thiele, J.; Borowitz, M.J.; Le Beau, M.M.; Bloomfield, C.D.; Cazzola, M.; Vardiman, J.W. The 2016 revision to the World Health Organization classification of myeloid neoplasms and acute leukemia. Blood 2016, 127, 2391-2405. [CrossRef] [PubMed]

42. Qi, X.; De Stefano, V.; Su, C.; Bai, M.; Guo, X.; Fan, D. Associations of antiphospholipid antibodies with splanchnic vein thrombosis: A systematic review with meta-analysis. Medicine 2015, 94. [CrossRef] [PubMed]

43. Connors, J.M. Thrombophilia Testing and Venous Thrombosis. N. Engl. J. Med. 2017, 377, $1177-1187$. [CrossRef] [PubMed]

44. Loffredo, L.; Pastori, D.; Farcomeni, A.; Violi, F. Effects of Anticoagulants in Patients with Cirrhosis and Portal Vein Thrombosis: A Systematic Review and Meta-analysis. Gastroenterology 2017, 153, 480-487. [CrossRef]

45. Magaz, M.; Alvarez-Larrán, A.; Colomer, D.; López-Guerra, M.; García-Criado, M.Á.; Mezzano, G.; Belmonte, E.; Olivas, P.; Soy, G.; Cervantes, F.; et al. Next generation sequencing in the diagnosis of non-cirrhotic splanchnic vein thrombosis. J. Hepatol. 2020. [CrossRef]

(C) 2020 by the authors. Licensee MDPI, Basel, Switzerland. This article is an open access article distributed under the terms and conditions of the Creative Commons Attribution (CC BY) license (http://creativecommons.org/licenses/by/4.0/). 